\title{
Self-Determination and Student Involvement in Standards-Based Reform
}

MICHAEL L. WEHMEYER

University of Kansas

SHARON FIELD

Wayne State University

BONNIE DOREN

University of Oregon

BONNIE JONES

U.S. Department of Education

CHRISTINE MASON

Cessi, Inc.

ABStRAct: Promoting self-determination has become "best practice" in the education of students with disabilities. We synthesize the decade's work in this area as a foundation for considering issues pertaining to promoting self-determination in light of the current educational context. We particularly examine the role of promoting self-determination in light of federal standards-based reform initiatives. We conclude that school reform efforts provide an opportunity to infuse instruction in self-determination into the education programs of all students, including students with disabilities. Many state and local standards include a focus on component elements of self-determined behavior and promoting self-determination enables students to perform more effectively within other content domains. The importance of personnel preparation to enable teachers to promote self-determination is discussed.

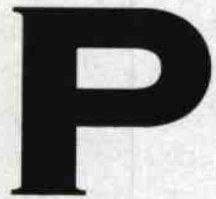

romoting the self-determination of students with disabilities became a focus of interest in special education research and practice in the late 1980 s. This initiative was stimulated with funding from the U.S. Department of Education's Office of Special Education Programs (OSEP) to "support model projects that identify the skills and characteristics necessary for self-determination, as well as the in-school and out-of-school experiences that lead to the development of self-determination" (Federal Register, Volume 54, No. 177, Thursday, September 14, 1989, p. 38166). Between 1990 and 1996, OSEP funded 26 model demonstration projects intended to develop practices and programs that would support self-determination for youth with disabilities (Ward \& Kohler, 1996). In 1992, OSEP grant competitions funded research pertaining to the develop- 
ment and evaluation of models of self-determination and assessment methods, materials, and strategies tied to those models. Additionally, numerous projects focused on self-determination and were funded through other competitions such as field-initiated research and outreach.

\section{SELF-DETERMINATIONAND STUDENTS WITH DISABILITIES}

Due largely to the federal emphasis on and funding to promote self-determination as a compo$n$ nt of the education of youth with disabilities, many resources are now available to support instruction to achieve this outcome. Such resources range from curricular materials and guides to instructional strategies and methods (Field \& Hoffman, 1996a; Field, Martin, Miller, Ward, \& Wehmeyer, 1998a; Test, Karvonen, Wood, Browder, \& Algozzine, 2000; Wehmeyer, Agran, \& Hughes, 1998), assessment tools (Abery, Stancliffe, Smith, McGrew, \& Eggebeen, 1995; Wehmeyer, 1996b; Wolman, Campeau, Dubois, Mithaug, \& Stolarski, 1994), teaching models (Wehmeyer, Palmer, Agran, Mithaug, \& Martin, 2000), model programs (Ward \& Kohler, 1996), position papers (Field, Martin, Miller, Ward, \& Wehmeyer, 1998b), and studentdirected planning programs (Halpern, Herr, Doren, \& Wolf, 2000; Martin \& Marshall, 1995; Wehmeyer \& Sands, 1998). The process of promoting self-determination has been explored across age ranges, from early childhood (Erwin \& Brown, 2000; Wehmeyer \& Palmer, 2000) to secondary education (Field \& Hoffman, 1996b), and across disability categories, including learning disabilities (Field, 1996), mental retardation and multiple disabilities (Gast et al., 2000; Wehmeyer,

\section{Due largely to the federal emphasis on and funding to promote self-determina- tion as a component of the education of youth with disabilities, many resources are now available to support instruction to achieve this outcome.}

1998, 2001), and autism (Fullerton, 1998). In a federally funded project to synthesize this growing literature base with regard to promoting and enhancing self-determination, Algozzine, Browder, Karvonen, Test, and Wood (2001) identified four primary focal points in the literature: (a) definitions and conceptual models of selfdetermination, (b) the importance and rationale of self-determination for students with disabilities, (c) strategies for promoting self-determination, and (d) effects of self-determination and student involvement instructional programs. A summary of findings in each area follows, although we combined information about strategies for promoting self-determination and effects of self-determination and student involvement because they both focus on the impact of self-determination on valued outcomes.

\section{DEFINING AND CONCEPTUALIZING \\ SELF-DETERMINATION}

There is a high level of consistency across the major definitions and conceptual frameworks for self-determination developed during the $1990 \mathrm{~s}$ (e.g., Abery, Rudrud, Arndt, Schauben, \& Eggebeen, 1995; Field \& Hoffman, 1994; Martin \& Marshall, 1995; Mithaug, 1996; Wehmeyer, 1996a, 1998, 2001). Field et al. (1998a, p. 2) summarized the various definitions of self-determination by stating that self-determined people apply "a combination of skills, knowledge and beliefs" that enable them "to engage in goal-directed, self-regulated, autonomous behavior. An understanding of one's strengths and limitations together with a belief in oneself as capable and effective are essential in self-determination. When acting on the basis of these skills and attitudes, individuals have greater ability to take control of their lives and assume the role of successful adults in our society." Field et al. further delineated the common components of self-determined behavior identified across multiple models of self-determination. These include (a) awareness of personal preferences, interests, strengths, and limitations; (b) ability to (i) differentiate between wants and needs, (ii) make choices based on preferences, interests, wants, and needs, (iii) consider multiple options and anticipate consequences for decisions, (iv) initiate and take action when needed, 
(v) evaluate decisions based on the outcomes of the previous decision and revise future decisions accordingly, (vi) set and work toward goals, (vii) regulate behavior, (viii) use communication, skills such as negotiation, compromise, and persuasion to reach goals, and (ix) assume responsibility for actions and decisions; (c) skills for problem-solving; (d) a striving for independence while recognizing interdependence with others; (e) self-advocacy and self-evaluation skills; (f) independent performance and adjustment skills; (g) persistence; (h) self-confidence; (i) pride; and (j) creativity.

\section{IMPORTANCE AND RATIONALE FOR ADDRESSING SELF-DETERMINATION}

Many of the articles focusing on selfdetermination have addressed why self-determination should be considered a central organizing concept in special education practice and policy (Algozzine et al., 2001). These reflect two perspectives: (a) a civil rights, empowerment, and self-advocacy perspective (e.g., Ward, 1996) that emphasizes the rights of people with disabilities to exert control in their lives; and (b) an educational effectiveness perspective (Field et al., 1998a; Wehmeyer, 1992; Wehmeyer \& Schwartz, 1997) that emphasizes the relevance of such efforts for improving educational outcomes. It should be noted that these two perspectives are not mutually exclusive, nor do supporters of one necessarily eschew the other.

The rationale to focus efforts to promote self-determination based on civil rights, empowerment, and self-advocacy is philosophically, rather than empirically-based. There are, however, some empirically-based studies that support the second perspective and demonstrate that enhanced selfdetermination improves the educational outcomes of youth with disabilities. For example, research has indicated that children who help choose school activities show enhanced motivation to perform those tasks and are more likely to achieve their goals (e.g., Benz, Lindstrom \& Yovanoff, 2000; Realon, Favell, \& Lowerre, 1990; Schunk, 1985). Wehmeyer and Schwartz (1997) measured the self-determination status of 80 students with mild mental retardation or learning disabilities in their final year of high school and then 1 year after high school. Students with higher self- determination scores were more likely to have expressed a preference to live outside the family home, have a savings or checking account, and be employed for pay. Eighty percent of students in the high self-determination group worked for pay 1 year after graduation, whereas only $43 \%$ of students in the low self-determination group did likewise. Among school leavers who were employed, youth who were in the high selfdetermination group earned significantly more per $\mathrm{hr}(M=\$ 4.26)$ than their peers in the low self-determination group $(M=\$ 1.93)$. Wehmeyer and Palmer (2003) conducted a second follow-up study, examining the adult status of 94 young people with cognitive disabilities (mental retardation or learning disability) 1 and 3 years postgraduation. These data replicated results from Wehmeyer and Schwartz. Finally, Sowers and Powers (1995) showed that instruction on multiple components related to self-determination increased the participation and independence of students with severe disabilities with respect to performing community activities.

\section{EFFECTIVENESS OF STRATEGIES FOR \\ PROMOTING SELF-DETERMINATION.}

The special education literature contains many recommended strategies to promote selfdetermination. According to Algozzine et al. (2001), the major types of strategies recommended in the literature are student involvement in educational planning and directly teaching skills to promote self-determination. In their meta-analysis of studies addressing the latter, Algozzine and colleagues found that the majority of intervention studies promoting skills related to self-determined behavior focused on adolescents and adults. Only $19.6 \%$ of the studies included children between the ages of 5-13 years, and 2\% of the studies focused on children under the age of 5 . Several authors writing in the self-determination literature have suggested that more research and development effort needs to be placed on the needs of younger children related to the development of self-determination (e.g., Abery \& Zajac, 1996; Burchard, 1996; Doll, Sands, Wehmeyer, \& Palmer, 1996; Palmer \& Wehmeyer, 2003). 
The majority of strategies recommended in the self-determination literature lack empirical validation. Although more than 450 articles have been published on the topic of self-determination, Algozzine and colleagues (2001) identified only 51 articles published during the period 1972-2000 that met the criteria they established for data-based, peer-reviewed studies on interventions to promote component elements of self-determined behavior. Of the 51 studies reviewed, only 22 met the criteria necessary to be included in a meta-analysis to determine effect sizes of the interventions. Nine of the interventions examined reported group data. The average effect size across these studies was 1.38 , with a standard deviation of 3.74 and a standard error of 0.37 . The effect size measurements indicated that most studies reported changes in self-determination related outcomes reflective of moderate gains as a result of instructional interventions. The singlesubject studies $(n=13)$ demonstrated stronger effect sizes. According to Algozzine et al., the median percentage of nonoverlapping data (PND) between the treatment and baseline phases was $95 \%$, with a range of $64 \%$ to $100 \%$ for the studies, indicating that participants acquired skills related to self-determination at a relatively high level.

Additionally, Wehmeyer, Palmer, et al. (2000) have designed and empirically validated a model of teaching to promote self-determination and student self-regulated problem-solving (the Self-Determined Learning Model of Instruction). Validation studies with adolescents (Agran, Blanchard, \& Wehmeyer, 2000; Palmer, Wehmeyer, Gipson, \& Agran, 2004; Wehmeyer, Palmer, et al., 2000) and elementary-age children (Palmer \& Wehmeyer, 2003) have shown that students with cognitive disabilities can self-regulate the instructional goal-setting process and self-direct learning that leads to the attainment of educationally valued outcomes and enhanced perceptions of selfdetermination.

\section{SELF-DETERMINATION AND STANDARDS-BASED REFORM}

The previous section provided a synopsis of the state-of-the-field with regard to knowledge and practice in promoting and enhancing the selfdetermination of children and youth with disabilities. It is an encouraging start considering the relative lack of focus on these issues prior to the 1990 OSEP initiative. However, the context in which the education of students with disabilities occurs has changed dramatically over the past decade. Specifically, the 1997 Amendments (Public Law 105-17) to the Individuals with Disabilities Education Act (IDEA) included requirements that the individualized education programs of all students with disabilities contain statements regarding how the child's disability affects involvement with and progress in the general curriculum, as well as measurable goals and program modifications to ensure such involvement and progress.

\section{The context in which the education of students with disabilities occurs has changed dramatically over the past decade.}

These "access to the general curriculum" requirements were implemented to ensure that students with disabilities were included in emerging standards-based reform and accountability systems. Standards-based reform efforts establish state and local content and student achievement standards in which content standards describe the knowledge, skills, and understanding that students should accomplish in specific content domains. Student achievement standards define the levels of achievement that exemplify proficiency, typically sequenced by grade or age. The curriculum is then developed to align with these standards and, in turn, teachers are prepared and supported to provide high-quality instructional methods, materials, and strategies to implement the curriculum. Finally, the establishment of high standards, the development of curriculum, and the implementation of high-quality instructional strategies are linked to multiple levels of accountability. That is, the content and student achievement standards are used as measurement criteria to evaluate student progress toward those stan- 
dards through state and district assessments of student performance.

The IDEA access mandates were intended to ensure that students with disabilities were not excluded from the accountability systems linked with standards-based reform. No Child Left Behind is explicit in its intent that all students will meet the same high-quality content standards. It is this alignment with standards-based reform and accountability mechanisms that constitutes the most dramatic element of the changing context in which the education of students with disabilities occurs. The self-determination initiative was introduced within the context of OSEP efforts to promote transition services and influence outcomes for students with disabilities. However, the access to the general curriculum initiative was introduced within the context of efforts to align special education practices with prevailing reform efforts and, largely, to impact student performance in core content areas. Emphasis on core content areas has been amplified by the steady progression of the implementation of assessmentbased accountability mechanisms aligned to state and local standards. This is accompanied by an increased emphasis on the importance of evidence-based practices to improve instruction in core content areas such as reading and math.

The concern articulated by policy leaders has been that if students with disabilities are not included in standards-based reform efforts, they will be excluded from the accountability system on which school improvement efforts are based and, thus, will be marginalized and excluded from efforts to improve academic performance. The same concern must be voiced for educational content areas that are perceived as "outside" of the domain of standards-based reform and accountability, including many transition-related instructions such as promoting self-determination (Kochhar-Bryant \& Bassett, 2003). Efforts to promote access to the general curriculum are not intended to de-emphasize the importance of functional and outcomes-oriented instructional experiences for youth with disabilities. The standards-based reform and accountability systems are designed, however, to place increased emphasis on content areas that are included in standards and tested on assessments linked to those standards. Thus, as educators and school districts are increasingly held accountable for outcomes related to district or state assessments, they will increasingly narrow the curriculum to those content areas for which accountability mechanisms are developed and implemented, including, potentially, the focus on self-determination.

We take the position in this article, however, that the current context of promoting access to the general curriculum provides the chance to more fully infuse efforts to promote selfdetermination into the general curriculum, and that instruction to promote self-determination and student involvement actually provides a means to promote the participation of students with disabilities in the general curriculum. There are two ways that promoting self-determination provides access to and promotes progress in the general curriculum.

First, state and local standards frequently include goals and objectives that pertain to component elements of self-determined behavior, including educational emphasis on teaching goal-setting, problem-solving, and decision-making skills. In virtually every set of state-adopted standards, students are expected to learn and apply effective problem-solving, decision-making, and goal-setting processes. Thus, teachers can promote progress in the general curriculum by teaching standards-based skills and knowledge related to the component elements of selfdetermined behavior.

Second, in addition to addressing the component elements of self-determined behavior when they occur in the general curriculum, teaching young people with and without disabilities self-regulation, self-management, problemsolving, goal-setting, and decision-making skills provides an effective means to enable students to engage with and progress through activities in the general curriculum more effectively. Several models exist to define efforts to promote access to the general curriculum for students with disabilities (Janney \& Snell, 2000; Nolet \& McLaughlin, 2000). A model proposed by Wehmeyer, Sands, Knowlton, and Kozleski (2002) focusing on access for students with more severe disabilities placed particular emphasis on the role of selfdetermination in two levels of curriculum modification to enable students to engage with and respond to the curriculum. 
The first level of modification involves curriculum adaptations. Curriculum adaptation refers to any effort to modify the representation or presentation of the curriculum or to modify the student's engagement with the curriculum to enhance access and progress (Center for Applied Special Technology [CAST], 1998-1999). Adaptations to the way curricular content is represented refer to the way in which the information in the curriculum is depicted or portrayed, specifically how curricular materials are used to depict information. The dominant representation mode is print, usually through texts, workbooks, and worksheets. There are a number of ways to change that representation, ranging from changing font size to using graphics. Adaptations in curriculum presentation modify the way teachers convey or impart information in the curriculum. Such presentation has, historically, been through written formats (chalkboards or overheads) or verbally (lectures). These primary means of presentation have drawbacks for many students who read ineffectively (or don't read at all) or who have difficulty attending to or understanding lecture formats. There are a variety of ways of changing the presentation mode, from using video sources to reading (or playing an audiotape of) written materials to Web-based information.

Curriculum adaptations that modify the student's engagement with the curriculum impact the ways students respond to the curriculum. Again, the typical means of student engagement within the curriculum involves written responses or, perhaps less frequently, oral responses or reports. However, students can respond or engage with the curriculum in multiple other ways, including "artwork, photography, drama, music, animation, and video" (CAST, 1998-1999). Each of these adaptations enable students to express their ideas and demonstrate their knowledge.

The second level of curricular modification to achieve access involves curriculum augmentation (Knowlton, 1998; Wehmeyer, Lattin, \& Agran, 2001; Wehmeyer et al., 2002). With curriculum augmentation, the standard curriculum is enhanced with "meta-cognitive or executive processing strategies for acquiring and generalizing the standard curriculum" (Knowlton, p. 100). Such augmentations do not change the curriculum, but add to or augment the curriculum with strategies for students to succeed within the curriculum. The most frequently identified curriculum augmentations instruct students in cognitive strategies or learning-to-learn strategies that enable them to perform more effectively with content in the general curriculum, including reading, writing, note-taking, memory, and test-taking strategies. Although primarily developed with students for learning disabilities (Deshler, Ellis, \& Lenz, 1996), these strategies can be used with other students.

Promoting self-determination contributes to both levels of curricular modification (adaptation and augmentation) to promote access to the general curriculum. For example, Kame'enui and Simmons (1999) identified one of the six basic design principles of curriculum adaptation to be the use of "conspicuous strategies." Kame'enui and Simmons noted:

To solve problems, students follow a set of steps or strategies. Many students develop their own strategies, but a considerable amount of time may be required for the student to identify the optimum strategy. For students with disabilities, such an approach is highly problematic because instructional time is a precious commodity and these learners may never figure out an efficient strategy. Learning is most efficient when a teacher can make it conspicuous or explicit. (p. 15)

Kame'enui and Simmons (1999), illustrated both the core role that problem-solving plays in learning and the difficulties students with disabilities experience as a function of their nonstrategic approach to content and activities and their difficulty with goal-oriented actions. Students who learn effectively set learning goals and objectives to reach those goals and then use problem-solving and self-regulation skills to tackle the activities to achieve those goals. Promoting selfdetermination includes efforts to teach problemsolving, goal- setting, and self-regulation or self-management skills. By augmenting the general curriculum to explicitly teach these skills, teachers are not only promoting self-determination, but are also providing skills students can apply to learning situations. Teaching students self-directed learning strategies serves as an effective curriculum augmentation as well, with skills such as self-monitoring or self-instruction serving 
Instructional Strategies $\left(S^{a}\right)$ :

- Teach individuals to use self-assessment, problem-solving, and other cognitive strategies to meet their needs.

- Use procedures to increase the individual's self-awareness, self-management, self-control, self-reliance, and self-esteem.

Learning Environments and Social Interactions $(S)$

- Teach self-advocacy.

- Create an environment that encourages self-advocacy and increased independence.

Instructional Planning ( $S$ )

- Involve the individual and family in setting instructional goals and monitoring progress.

- Design and implement instructional programs that address independent living and career education for individuals.

- Design and implement curriculum and instructional strategies for medical self-management procedures.

Collaboration (S)

- Assist individuals with exceptional learning needs and their families in becoming active participants in the educational team.

- Plan and conduct collaborative conferences with individuals with exceptional learning needs and their families.

aS=Skills.

as effective "strategies" that students can, in turn, apply to the learning process.

\section{IMPLICATIONS FOR IMPROVING PRACTICE}

If promoting self-determination is important to gain access to the general curriculum, it is critically important to focus attention on issues pertaining to personnel preparation in this area. Research suggests that teachers working with students with cognitive disabilities value selfdetermination but do not necessarily incorporate learning experiences to promote this outcome into the educational programs of their students (Thoma, Nathanson, Baker, \& Tamura, 2002; Wehmeyer, Agran, \& Hughes, 2000). This is at least partly because, as teachers themselves report, they lack the knowledge and skills to do this successfully (Wehmeyer, Agran, et al., 2000). Mason, Field, and Sawilowsky (2004) report similar findings. It is useful, therefore, to consider what might serve as a catalyst to improve teacher knowledge and skills in this area.

Using the Council for Exceptional Children's (CEC) performance-based standards for the preparation of special educators, and the knowl- edge and skills based in those standards, which have been adopted by the National Council for Accreditation of Teacher Education (NCATE; Council for Exceptional Children, 2003) for program accreditation, provides one means to ensure that teachers gain knowledge and skills in the area of self-determination. The standards that most directly address these component elements of selfdetermined behavior are nine skill standards under the Instructional Strategies, Learning Environments and Social Interactions, Instructional Planning, and Collaboration domains (Table 1).

There is only limited information available regarding how preservice programs are addressing self-determination in the knowledge and skill standards. Recently, CEC's Division on Career Development and Transition (DCDT) reported findings from a national survey of personnel preparation practices in transition that provide some indication, albeit indirect, with regard to the degree to which such standards might be addressed (Anderson et al., 2003). This survey was completed by 280 higher education department chairpersons and 247 higher education instructors who were identified as delivering content related to transition. The transition-related competencies section of the survey included all 
the transition-relevant standards from CEC's Common Core of Knowledge and Skills Essential for Beginning Special Education Teachers (CEC, $1997-$ 1999), and CEC's Standards for Preparation of Transition Specialists (CEC, 2000). The most common delivery method was to infuse transition content into several courses, with $69.5 \%$ of department chairs and $67.6 \%$ of instructors reporting use of this strategy. Slightly less than half of the respondents ( $43.3 \%$ of department chairs; $44.8 \%$ of instructors) also devoted an entire course or courses to some or all of the transition competencies covered in their programs. Less than $12 \%$ of respondents in both groups reported infusing transition content into one class only. Nine percent of respondents indicated that little, if any, transition curriculum was addressed in their program. Finally $7.1 \%$ of respondents indicated that they include $n o$ transition content in their special education teacher preparation program (Anderson et al.).

Department chairs and instructors differed slightly with regard to the relative importance they placed on each knowledge and skills domain, but, unfortunately, domains in which the selfdetermination knowledge and skills standards are included (e.g., Instructional Planning, Learning Environments and Social Interactions, and Instructional Strategies) ranked generally low by both groups. Instructional Planning ranked sixth in importance (out of 10 domains) for chairpersons and instructors, and Instructional Strategies ranked seventh in importance for chairpersons and eighth for instructors. Learning Environments ranked higher, fourth for chairpersons and fifth for instructors, but this section also included issues pertaining to behavior and classroom management, perhaps accounting for the higher profile.

In summary, the DCDT survey indicated that content related to transition, in general, is most likely to be infused into content in other courses (often methods courses) and that domains that include the self-determination related knowledge and skills standards were not ranked high in importance by either departmental chairpersons or instructors. Anderson and colleagues (2003) noted that although infusing transition content into other courses is a legitimate way to deliver such content, it is more likely that infused con- tent does not get adequately addressed. This may be particularly so for content that is not as highly valued, and that is not included in state or district standards. Additionally, now that several studies have shown that teachers do not feel prepared to instruct students in these skills (Mason et al., 2004; Wehmeyer, Agran, et al., 2000), personnel preparation programs should review their offerings and determine not only where these standards are currently being addressed, but also the adequacy of instruction for these skill standards.

Another professional development issue relates to the preparation of general educators and the extent of knowledge that is needed or recommended to prepare them to teach all students, including students with disabilities. This issue is particularly important because, according to the latest report to Congress on the implementation of IDEA, students with disabilities, on average, receive $80 \%$ of their instruction in general education classrooms. The importance of this issue was further illustrated in research conducted by Zhang (2001), who examined the opportunities students with disabilities had to engage in classroom activities related to self-determination. Students had fewer such opportunities in the general education classroom than in a self-contained classroom.

\section{SELF-DETERMINATION, ACCESS TO \\ General CuRRICULUM, aND TEACHER \\ PREPARATION}

Preservice training and focused innovations that restructure teacher time and effort rather than add new responsibilities are needed if teachers are to become proficient in implementing strategies that adapt and augment the general curriculum to explicitly teach self-determination skills. For these efforts to be successful, they must be aligned and coordinated with emerging trends emanating from national efforts in general education reform (Halpern, 2000.)

Numerous authors have reported that the current dual system of teacher education, whereby general educators and special educators are trained and receive practice in teaching very separate, distinct types of content and types of students, does not prepare teachers to meet the diverse needs of learners in schools (Mercer, Lane, Jordan, Allsopp \& Eiselle, 1996; Skrtic, Sailor, \& 
Gee, 1996; Villa, Thousand, \& Chapple, 1996). Few special education teachers have been trained in the area of standards-based education and assessment (Sands, Adams, \& Stout, 1995), and general educators feel unprepared to successfully include students with disabilities in their classes (Lesar, Benner, Habel, \& Coleman, 1997; Tomlinson, et al., 1997). General educators are concerned about how students with disabilities will master increased amounts of new content, meet higher standards, and demonstrate more complex cognitive processing. Special educators are concerned with how to support students with disabilities to attain these standards as well as how to find time to teach other critical domains (i.e., self-determination) and thus how to apply curriculum standards in these domains (U.S. Department of Education, 2001). Special educators are also being challenged to collaborate with general education teachers in order to help students with disabilities meet the higher standards of educational reform.

For teachers to meet the challenges of developing, augmenting, and adapting curriculum and instruction to respond to states' core content standards and self-determination knowledge and skills, both general and special education trainees must be knowledgeable about each of these components. General and special education teachers must achieve a shared language and shared philosophies about the education of all students. This cannot happen until university training programs, state departments of education, and local schools develop partnerships that provide all educators with opportunities to learn, experiment, consult with others, and reflect on their practices (Johnston, 1997; Osguthorpe, Harris, Harris, \& Black, 1995).

Clearly, future special education teachers, as well as general education teachers, must be better trained to collaborate effectively to provide appropriate and effective instruction to students with disabilities within the general curriculum. A unified preservice training program for general and special education trainees is needed (Blanton, Griffin, Winn, \& Pugach, 1997; McLeskey, Henry, \& Axelrod, 1999). The outcomes of a unified program would include (a) development of a common core of knowledge and skills, including knowledge and skills in adapting the general cur- riculum to explicitly teach self-determination skills; (b) development of roles and responsibilities that general and special educators need in schools; and (c) provision of field-based experiences that are well integrated with university course work and encourage collaboration between educators. Achieving these outcomes could be accomplished by the following:

- Courses taken by special education trainees with general education trainees that focus on (a) co-design of instruction to fully integrate core academic knowledge and skills with selfdetermination knowledge and skills, (b) co-design of adaptations to the general curriculum to ensure successful participation of students with disabilities, (c) co-design and use of assessment

Clearly, future special education teachers, as well general education teachers, must be better trained to collaborate effectively to provide appropriate and effective instruction to students with disabilities within the general curriculum.

techniques to document student progress on knowledge and skills, and (d) collaboration and teamwork.

- Seminars that allow special and general education trainees to interact with each other and provide information and techniques in collaboration, lesson design, and co-teaching.

- Student teaching experiences that include coteaching assignments.

Finally, teacher preparation programs should model practices to be used by trainees in the field. These programs would explicitly teach knowledge and skills to enhance self-determination by embracing and implementing learner-centered teaching and assessment within teacher preparation program components (Weimer, 2002). A unified teacher education program would better prepare both special and general education trainees to implement (a) standards-based education, (b) performance assessments, (c) curricular adaptations that explicitly provide instruction on self-determination knowledge and skills 
If teachers are to promote the self-determination of students, it is imperative that they model self-determined behavior in the classroom.

within the context of any academic core content area, and (d) methods to evaluate student progress on learning these knowledge and skills.

If teachers are to promote the self-determination of students, it is imperative that they model self-determined behavior in the classroom. Therefore, it is important that initial preparation and staff development programs support the development of knowledge, skills, and beliefs that help educators to further develop their own selfdetermination. In a recent study, Hoffman, Field, and Fullerton (2003) asked educators to indicate the importance of various components of self-determination to their roles as special or general educators or administrators. On a scale of 1 to 5 (1 $=$ low; $5=$ high), the mean rating of importance for the self-determination components was 4.62. The minimum rating was 3.95 and the maximum rating was 4.92 . The 60 educators involved provided over 246 examples or explanations from their careers indicating how self-determination competencies are related to their effectiveness as educators. Clearly, if we expect teachers to provide instruction that leads to increased student self-determination, it is imperative that instruction and support to enhance the self-determination of educators is provided in educators' initial preparation and ongoing staff development. Examples of such instruction and support include activities that (a) assist educators to define their educational philosophy and purpose in their careers, (b) help teachers clarify their strengths and weaknesses, (c) develop skills in setting and achieving goals based on personal philosophy and vision, (d) further develop personal support systems, and (e) develop the ability to reflect on and learn from experiences.

\section{CONCLUSION}

Several points emerge from this "pulse check." First, there are several empirically validated mod- els of self-determination that can serve as a foundation for designing, evaluating, and implementing instructional methods, materials, and strategies to promote self-determination. Second, although there have been a number of promising methods, materials, and strategies to promote self-determination that have emerged over the last decade, it remains the case that too few of them have been subjected to empirical validation. Given the current political climate emphasizing scientifically valid educational strategies, it is critical that existing strategies, methods, and curricular materials be evaluated using high-quality, rigorous research designs. Third, there is an emerging database that suggests that promoting and enhancing self-determination contributes to more positive educational and adult outcomes for students with disabilities and that there are viable strategies that result in enhanced self-determination. However, there is a need to expand that database with additional research. Fourth, there needs to be a concentrated focus on personnel preparation to teach teachers how to promote self-determination and how to infuse this into the general curriculum.

\section{REFERENCES}

Abery, B., Rudrud, L., Arndt, K., Schauben, L., \& Eggebeen, A. (1995). Evaluating a multicomponent program for enhancing the self-determination of youth with disabilities. Intervention in School and Clinic, 30(3), 170-179.

Abery, B., \& Zajac, R. (1996). Self-determination as a goal of elementary education. In D. J. Sands \& M. L. Wehmeyer (Eds.), Self-determination across the lifespan: Independence and choice for people with disabilities (pp. 169-196). Baltimore: Paul H. Brookes.

Abery, B. H., Stancliffe, R. J., Smith, J., McGrew, K., \& Eggebeen, A. (1995). Minnesota Opportunities and Exercise of Self-Determination Scale-Adult Edition. Minneapolis, MN: University of Minnesota, Institute on Community Integration.

Agran, M., Blanchard, C., \& Wehmeyer, M. L. (2000). Promoting transition goals and self-determination through student-directed learning: The Self-Determined Learning Model of Instruction. Education and Training in Mental Retardation and Developmental Disabilities, 35, 351-364. 
Algozzine, B., Browder, D., Karvonen, M., Test, D. W., \& Wood, W. M. (2001). Effects of interventions to promote self-determination for individuals with disabilities. Review of Educational Research, 71, 219-277.

Anderson. D., Kleinhammer-Tramill, J., Morningstar, M., Blalock, G., Kohler, P., Lehmann, J., \& Wehmeyer, M. (2003). What is happening in personnel preparation in transition? A national survey. Career Development for Exceptional Individuals, 26, 145-160.

Benz, M., Lindstrom, L., \& Yovanoff, P. (2000). Improving graduation and employment outcomes of students with disabilities: Predictive factors and student perspectives. Exceptional Children, 66, 509-529.

Blanton, L., Griffin, C., Winn, J., \& Pugach, M. (1997). Teacher education in transition: Collaborative programs to prepare general and special educators. Denver, CO: Love.

Burchard, S. (1996). Mastering the developmental challenges of childhood and adolescence. In L. E. Powers, G. H. S. Singer, \& J. Sowers (Eds.), Promoting selfcompetence in youth with disabilities: On the road to autonomy (pp. 111-145). Baltimore: Paul H. Brookes.

Center for Applied Special Technology. (1998-1999). The National Center on Accessing the General Curriculum [Electronic version]. Retrieved June 25, 2003, from http://www.cast.org/ncad

Council for Exceptional Children. (1997-1999). Common core of knowledge and skills essential for beginning special education teachers. Retrieved March 4, 2004, from http://www.cec.sped.org/ps/ps-entry

Council for Exceptional Children. (2000). Standards for preparation of transition specialists. Retrieved March 4, 2004, from http://www.cec.sped.org/ $\mathrm{ps} /$ transition.doc

Council for Exceptional Children. (2003). Council for Exceptional Children Professional Standards. Retrieved March 4, 2004, from http://www.cec.sped.org/ps/.

Deshler, D. D., Ellis, E. S., \& Lenz, B. K. (1996). Teaching adolescents with learning disabilities: Strategies and methods (2nd ed.). Denver, CO: Love.

Doll, B., Sands, D. J., Wehmeyer, M. L., \& Palmer, S. (1996). Promoting the development and acquisition of self-determined behavior. In D. J. Sands \& M. L. Wehmeyer (Eds.), Self-determination across the life span: Independence and choice for people with disabilities (pp. 65-90). Baltimore: Paul H. Brookes.

Erwin, E. J., \& Brown, F. (2000, November). Variables that contribute to self-determination in early childhood. TASH Newsletter, 26(3), 8-10.

Federal Register, Volume 54, No. 177, Thursday, September 14, 1989, p. 38166.
Field, S. (1996). Self-determination instructional strategies for youth with learning disabilities. Journal of Learning Disabilities, 29, 40-52.

Field, S., \& Hoffman, A. (1994). Development of a model for self-determination. Career Development for Exceptional Individuals. 17, 159-169.

Field, S., \& Hoffman, A. (1996a). Steps to self-determination. Austin, TX: PRO-ED.

Field, S., \& Hoffman, A. (1996b). Promoting self-determination in school reform, individualized planning, and curriculum efforts. In D. J. Sands \& M. L. Wehmeyer (Eds.), Self-determination across the life span: Independence and choice for people with disabilities (pp. 197-213). Baltimore: Paul H. Brookes.

Field, S., Martin, J., Miller, R., Ward, M., \& Wehmeyer, M. (1998a). A practical guide to teaching self-determination. Reston, VA: Council for Exceptional Children.

Field, S., Martin, J., Miller, R., Ward, M., \& Wehmeyer, M. (1998b). Self-determination in career and transition programming: A position statement of the Council for Exceptional Children. Career Development for Exceptional Individuals, 21, 113-128.

Fullerton, A. (1998). Putting feet on my dreams: Involving students with autism in life planning. In M. L. Wehmeyer \& D. J. Sands (Eds.), Making it happen: Student involvement in education planning, decisionmaking and instruction (pp. 279-296). Baltimore: Paul H. Brookes.

Gast, D. L., Jacobs, H. A., Logan, K. R., Murray, A. S., Holloway, A., \& Long, L. (2000). Pre-session assessment of preferences for students with profound multiple disabilities. Education and Training in Mental Retardation and Developmental Disabilities, 35, 393 405.

Halpern, A. S. (2000). Federal funding trends for national transition projects. In D. R. Johnson \& E. J. Emanuel (Eds.), Issues influencing the future of transition programs and services in the United States (pp. 39-53). Minneapolis, MN: Institute on Community Integration, University of Minnesota.

Halpern, A. S., Herr, C. M., Doren, B., \& Wolf, N. K. (2000). Next S. T.E.P.: Student transition and educational planning. Austin, TX: PRO-ED.

Hoffman, A., Field, S., \& Fullerton, A. (2003). Knowledge, skills and beliefs that support the self-determination of educator. Manuscript submitted for publication.

Janney, R., \& Snell, M. (2000). Teachers' guides to inclusive practices: Modifying schoolwork. Baltimore: Paul $\mathrm{H}$. Brookes. 
Johnston, M. (1997). Contradictions in collaboration: New thinking on school/university partnerships. New York: Teachers College, Columbia University.

Kame'enui, E. J., \& Simmons, D. C. (1999). Toward successful inclusion of students with disabilities: The architecture of instruction. Arlington, VA: Council for Exceptional Children.

Knowlton, E. (1998). Considerations in the design of personalized curricular supports for students with developmental disabilities. Education and Training in Mental Retardation and Developmental Disabilities, 33, 95-107.

Kochhar-Bryant, C., \& Bassett, D. (2003). Aligning transition and standards-based education: Issues and strategies (pp. 25-40). Arlington, VA: Council for Exceptional Children.

Lesar, S., Benner, S. M., Habel, J., \& Coleman, L. (1997). Preparing general education teachers for inclusive settings: A constructivist teacher education program. Teacher Education and Special Education, 20, 204-220.

Martin, J. E., \& Marshall, L. H. (1995). ChoiceMaker: A comprehensive self-determination transition program. Intervention in School and Clinic, 30, 147-156.

Mason, C., Field, S., \& Sawilowsky, S. (2004). Implementation of self-determination activities and student participation in IEPs. Exceptional Children 70, 421435.

McLeskey, J., Henry, D., \& Axelrod, M. I. (1999). Inclusion of students with learning disabilities: An examination of data from reports to Congress. Exceptional Children, 66, 55-66.

Mercer, C. D., Lane, H. B., Jordan, L., Allsopp, D. H., \& Eiselle, M. R. (1996). Empowering teachers and students with instructional choices in inclusive settings. Remedial and Special Education, 17, 226-236.

Mithaug, D. E. (1996). The optimal prospects principle: A theoretical basis for rethinking instructional practices for self-determination. In D. J. Sands \& M. L. Wehmeyer (Eds.), Self-determination across the life span: Independence and choice for people with disabilities (pp. 147-165). Baltimore: Paul H. Brookes.

Nolet, V., \& McLaughlin, M. (2000). Accessing the general curriculum. Thousand Oaks, CA; Corwin Press.

Osguthorpe, R. T., Harris, R. C., Harris, M. F., \& Black, S. (Eds.). (1995). Partner schools: Centers for educational research. San Fransico: Jossey-Bass.

Palmer, S., \& Wehmeyer, M. L. (2003). Promoting self-determination in early elementary school: Teaching self-regulated problem-solving and goal setting skills. Remedial and Special Education, 24, 115-126.
Palmer, S. B., Wehmeyer, M. L., Gipson, K., \& Agran, M. (2004). Promoting access to the general curriculum by teaching self-determination skills. Exceptional Children, 70, 407-420.

Realon, R. E., Favell, J. E., \& Lowerre, A. (1990). The effects of making choices on engagement levels with persons who are profoundly mentally handicapped. Education and Training in Mental Retardation, 25, 248-254.

Sands, D. J., Adams, L., \& Stout, D. M. (1995). A statewide exploration of the nature and use of curriculum in special education. Exceptional Children, 62, 6883.

Schunk, D. H. (1985). Participation in goal setting: Effects on self-efficacy and skills on learning disabled children. The Journal of Special Education, 19, 307-316. Skrtic, T. M., Sailor, W., \& Gee, K. (1996). Voice, collaboration, and inclusion: Democratic themes in educational and social reform initiatives. Remedial and Special Education, 17, 142-157.

Sowers, J., \& Powers, L. (1995). Enhancing the participation and independence of students with severe physical and multiple disabilities in performing community activities. Mental Retardation, 33, 209-220.

Test, D. W., Karvonen, M., Wood, W. M., Browder, D., \& Algozzine, B. (2000). Choosing a selfdetermination curriculum: Plan for the future. TEACHING Exceptional Children, 33(2), 48-54.

Thoma, C. A., Nathanson, R., Baker, S. R., \& Tamura, R. (2002). Self-determination: What do special educators know and where do they learn it? Remedial and Special Education, 23, 242-247.

Tomlinson, C. A., Callahan, C. M., Tomchin, E. M., Eiss, N., Imbeau, M., \& Landrum, M. (1997). Becoming architects of communities of learning: Addressing academic diversity in contemporary classrooms. Exceptional Children, 63, 269-282.

U.S. Department of Education. (2001). Twenty-third annual report to Congress on the implementation of the Individuals with Disabilities Education Act. Washington, DC: Author.

Villa, R. A., Thousand, J. S., \& Chapple, J. W. (1996). Preparing teachers to support inclusion: Preservice and inservice programs. Theory and Practice, 35, 42-50.

Ward, M. \& Kohler, P. (1996). Teaching self-determination: Content and process. In L. E. Powers, G. H. S. Singer, \& J. Sowers (Eds.), On the road to autonomy (pp. 275-290). Baltimore: Paul H. Brookes

Ward, M. J. (1996). Coming of age in the age of selfdetermination: A historical and personal perspective. In D. J. Sands \& M. L. Wehmeyer (Eds.), Self-determination across the life span: Independence and choice for peo- 
ple with disabilities (pp. 1-16). Baltimore: Paul H. Brookes.

Wehmeyer, M. L. (1992). Self-determination and the education of students with mental retardation. Education and Training in Mental Retardation, 27, 302-314.

Wehmeyer, M. L. (1996a). Self-determination as an educational outcome: Why is it important to children, youth and adults with disabilities? In D. J. Sands \& M. L. Wehmeyer (Eds.), Self-determination across the life span: Independence and choice for people with disabilities (pp. 15-34). Baltimore: Paul H. Brookes.

Wehmeyer, M. L. (1996b). A self-report measure of self-determination for adolescents with cognitive disabilities. Education and Training in Mental Retardation and Developmental Disabilities, 31, 282-293.

Wehmeyer, M. L. (1998). Self-determination and individuals with significant disabilities: Examining meanings and misinterpretations. Journal of the Association for Persons with Severe Handicaps, 23, 5-16.

Wehmeyer, M. L. (2001). Self-determination and mental retardation. In L. M. Glidden (Ed.), International review of research in mental retardation (Vol. 24, pp. 148). San Diego, CA: Academic Press.

Wehmeyer, M. L., Agran, M., \& Hughes, C. (1998). Teaching self-determination to students with disabilities: Basic skills for successful transition. Baltimore: Paul $\mathrm{H}$. Brookes.

Wehmeyer, M. L., Agran, M., \& Hughes, C. (2000). A national survey of teachers' promotion of selfdetermination and student-directed learning. Journal of Special Education, 34, 58-68.

Wehmeyer, M. L., Lattin, D., \& Agran, M. (2001). Promoting access to the general curriculum for students with mental retardation: A decision-making model. $E d$ ucation and Training in Mental Retardation and Developmental Disabilities, 36, 329-344.

Wehmeyer, M. L., \& Palmer, S. (2000). Promoting the acquisition and development of self-determination in young children with disabilities. Early Education and Development, 11, 465-481.

Wehmeyer, M. L., \& Palmer, S. B. (2003). Adult outcomes for students with cognitive disabilities three years after high school: The impact of self-determination. Education and Training in Developmental Disabilities, 38, 131-144.

Wehmeyer, M. L., Palmer, S. B., Agran, M., Mithaug, D. E., \& Martin, J. (2000). Teaching students to become causal agents in their lives: The self-determining learning model of instruction. Exceptional Children, 66, 439-453.
Wehmeyer, M. L., \& Sands, D. J. (1998). Making it happen: Student involvement in education planning, decision-making and instruction. Baltimore: Paul $\mathrm{H}$. Brookes.

Wehmeyer, M. L., Sands, D. J., Knowlton, E. H., \& Kozleski, E. (2002). Teaching students with mental retardation: Promoting access to the general curriculum. Baltimore: Paul H. Brookes.

Wehmeyer, M. L., \& Schwartz, M. (1997). Selfdetermination and positive adult outcomes: A followup study of youth with mental retardation or learning disabilities. Exceptional Children, 63, 245-255.

Weimer, M. (2002). Learner-centered teaching: Five key changes to practice. San Francisco: Jossey-Bass

Wolman, J., Campeau, P., Dubois, P., Mithaug, D., \& Stolarski, V. (1994). AIR self-determination scale and user guide. Palo Alto, CA: American Institute for Research.

Zhang., D. (2001). Self-determination and inclusion: Are students with mild mental retardation more selfdetermined in regular classrooms? Education and Training in Mental Retardation and Developmental Disabilities, 36, 357-362.

\section{ABOUT THE AUTHORS}

Michael L. Wehmeyer (CEC \#665), Associate Professor, Department of Special Education and Director, Kansas University Center on Developmental Disabilities, University of Kansas, Lawrence. SHARON FIELD (CEC \#1), Associate Professor (Research), College of Education, Wayne State University, Detroit, Michigan. BONNIE DOREN (Oregon Federation), Research Associate/Assistant Professor, Special Education, University of Oregon, Eugene. BONNIE JONES (CEC \#45), Education Research Analyst, Research to Practice Division, Office of Special Education Programs, U.S. Department of Education, Washington, DC. CHRISTINE MAsON (CEC \#192), Educational Consultant, and Senior Research Scientist, Cessi, Inc., McLean, Virginia.

Manuscript received May 2003; accepted June 2003. 
Copyright of Exceptional Children is the property of Council for Exceptional Children and its content may not be copied or emailed to multiple sites or posted to a listserv without the copyright holder's express written permission. However, users may print, download, or email articles for individual use. 